\title{
Palladium(II)-Catalyzed Efficient Synthesis of Wedelolactone and Evaluation as Potential Tyrosinase Inhibitor
}

\author{
Huidan Huang ${ }^{1}$, Jianqiu Chen ${ }^{1, *}$, Jie Ren ${ }^{2}$, Chaofeng Zhang ${ }^{2, *}$ and Fei Ji ${ }^{1, *}$ \\ 1 College of Engineering, China Pharmaceutical University, \#639 Longmian Avenue, Jiangning District, \\ Nanjing 211198, China; zgykdxbj1@163.com \\ 2 State Key Laboratory of Natural Medicines, Research Department of Pharmacognosy, China Pharmaceutical \\ University, \#639 Longmian Avenue, Jiangning District, Nanjing 211198, China; cpubj1@163.com \\ * Correspondence: cjq_1980@163.com (J.C.); chaofengzhang@163.com (C.Z.); jifei672453142@126.com (F.J.); \\ Tel.: +86-1381-385-9949 (J.C. \& C.Z. \& F.J.)
}

Academic Editor: Marc C. Kimber

Received: 26 September 2019; Accepted: 13 November 2019; Published: 15 November 2019

check for updates

\begin{abstract}
Tyrosinase is an enzyme widely distributed in nature, which has multiple functions, especially in the melanin biosynthesis pathway. Despite the few clinically available tyrosinase inhibitors for whitening, a great demand remains for novel compounds with low side effects in terms of potential carcinogenicity and improved clinical efficacy. A natural product, wedelolactone (WEL), with a polyhydroxyl moiety, attracted our attention as a potential tyrosinase inhibitor. Before we studied the biological activity of the natural product, a synthetic methodological research was firstly carried to obtain enough raw material. WEL could be obtained efficiently through palladium-catalyzed boronation/coupling reactions and 2,3-dicyano-5,6-dichlorobenzoquinone (DDQ)-involved oxidative deprotection/annulation reactions. Immediately after, the natural product was proven to be an efficient tyrosinase inhibitor. In conclusion, we developed a mild and efficient approach for the preparation of WEL, and the natural product was disclosed to have anti-tyrosinase activity, which could be widely used in multiple fields.
\end{abstract}

Keywords: wedelolactone (WEL); tyrosinase; Suzuki-Miyaura reaction; inhibitors

\section{Introduction}

Tyrosinase (EC 1.14.18.1) is an enzyme widely distributed in nature, which has multiple functions, especially in the melanin biosynthesis pathway [1]. The enzyme can catalyze L-tyrosine to L-3,4-dihydroxyphenylalanine (L-DOPA), with further oxidation to dopaquinone [2]. Dopaquinone transforms from brown to black through several reactions. Abnormal melanin production, including melasma, freckles, lentigo, senilis, and other forms of melanin hyperpigmentation could be a serious aesthetic problem $[2,3]$. In addition, tyrosinase is also involved in the defensive and developmental functions of pests [4]. Excessive dopaquinone was also reported to cause neurodegeneration related to Parkinson's disease [5]. Thus, many tyrosinase inhibitors are applied in cosmetics and pharmaceutical products [6]. Despite the few clinically available tyrosinase inhibitors for whitening, a great demand remains for novel compounds with low side effects in terms of potential carcinogenicity and improved clinical efficacy $[7,8]$. Obviously, more efforts are still needed in that direction; therefore, we recently focused our interest on discovering novel tyrosinase inhibitors.

Compounds with the polyhydroxyl moiety were proven to be potential tyrosinase inhibitors [9-11]. Recently, our group undertook research on a natural product with a polyhydroxyl moiety named wedelolactone (WEL), which is derived from the medical plant Eclipta prostrata [12]. Although a wide 
range of pharmacological activities of WEL were reported, there is less information on the inhibitory effect and reversibility of WEL on tyrosinase. Thus, the inhibitory activity and mechanism of WEL toward tyrosinase deserves deeper investigation; however, but the present knowledge on synthesis of the natural product is limited. Although several groups invested substantial effort in the preparation of WEL, these methods had several disadvantages, including a time-consuming nature with complicated synthetic approaches [13-15].

Among these methods, two routes listed in Figure 1 are commonly recognized by the industry. However, both methods have several disadvantages. The first method (reported by Yang [14]) involves a crucial intermediate, phenyl acetylene, which is difficult to prepare. The route has a low $15 \%$ overall yield with a long linear sequence (total of 12 steps), and it is rarely applied to access a variety of WEL analogues for structure transformations. The second method (reported by Lee et al. [13]) employs toxic organotin and organomercurial reagents, which limit industrial production and increase operation complexity. In addition, both methods can only obtain the natural products on a small scale. As the present methods are imperfect and unsatisfactory for further investigation of WEL as an efficient tyrosinase inhibitor, the development of a facile, versatile, and mild approach is urgently needed.

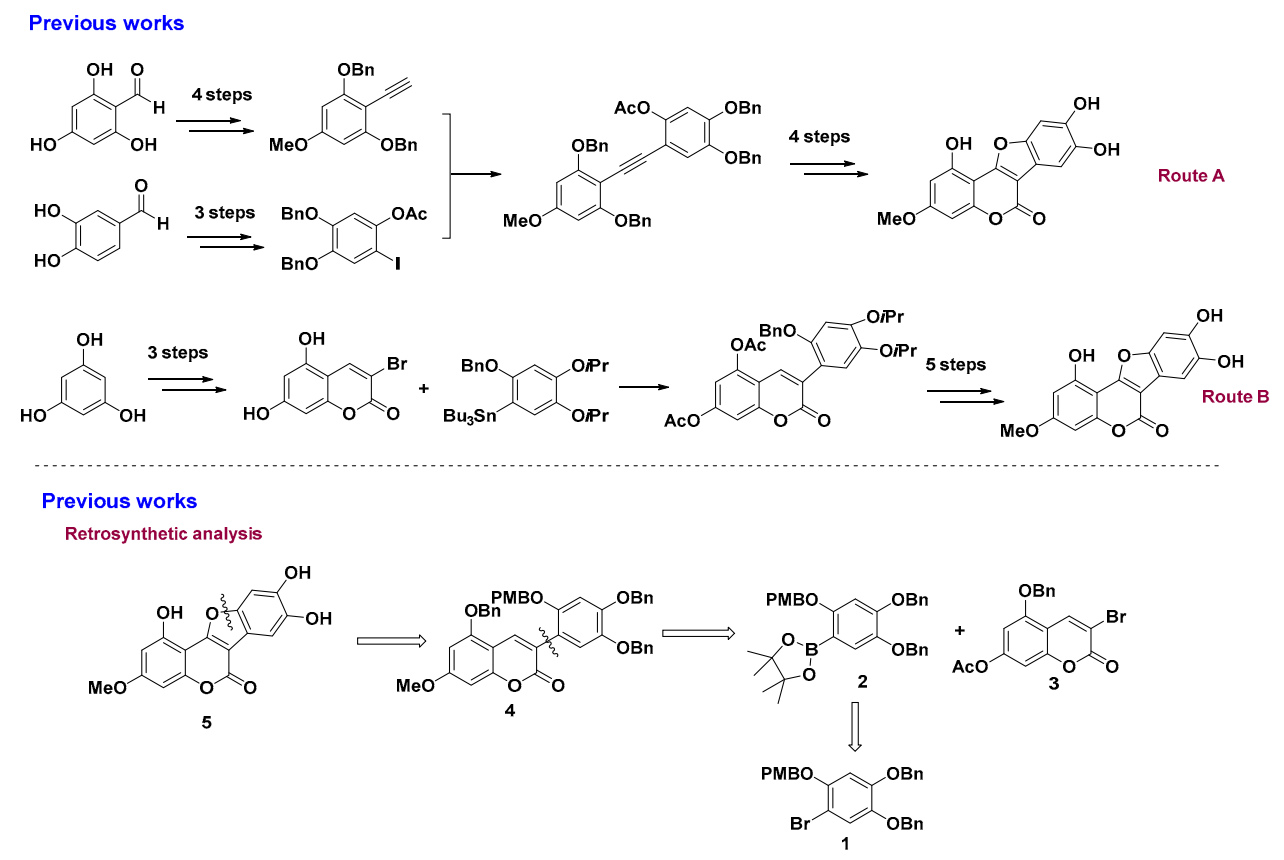

Figure 1. Reported synthesis routes of wedelolactone (WEL) and our proposal.

\section{Results and Discussion}

\subsection{Palladium(II)-Catalyzed Efficient Synthesis of WEL}

Retrosynthetically, WEL could be logically disconnected by the ring opening of furan to afford the intermediate 4 , which is further disconnected by $C-C$ bond cleavage to trace back to the intermediate 3-bromo-5-benzyloxy-7-acetoxyl-2-chromenone 3 and the readily prepared 4,5-dibenzyloxy-2-(4-methoxybenzyl)oxy-phenyl boronic ester 2 (Scheme 1). This similar synthetic strategy was ever used by Shen for the synthesis of hirtellanine A [16]. Synthetically, we expected that polysubstituted coumarin 4 could be obtained by $\mathrm{Pd}(\mathrm{II})$-catalyzed Suzuki-Miyaura coupling of 3-bromocoumarin 3 and polysubstituted phenyl boronate ester 2 which could be generated by a $\mathrm{Pd}(\mathrm{II})$-catalyzed boronation reaction of the polysubstituted bromobenzene 1 . The coupling product 4 then underwent a DDQ-oxidation deprotection/annulation reaction to deliver the final product WEL 5. 


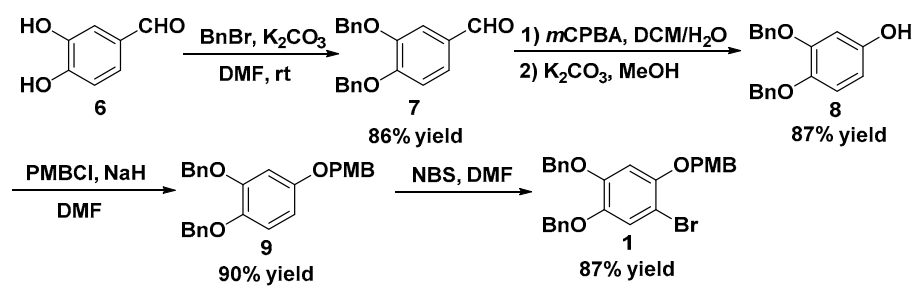

Scheme 1. Synthesis of polysubstituted bromobenzene 1.

In the beginning of our synthesis, we focused on the generation of the polysubstituted bromobenzene 1 (Scheme 1). Selective protection of the three phenolic hydroxyl groups presented a big synthetic challenge. After reviewing the literature [16,17], we chose the commercially available 3,4-dihydroxybenzaldehyde 6 as the starting material to provide the polysubstituted bromobenzene 1 via the $m$ CPBA-mediated Baeyer-Villiger oxidation strategy, which resolved the selective protection of phenolic groups. Synthetically, protection of the phenol groups of 3,4-dihydroxy-benzaldehyde 6 with benzyl bromide afforded 3,4-bis(benzyloxy)benzaldehyde 7 in $86 \%$ yield, which subsequently underwent $m$ CPBA-mediated oxidation and hydrolysis to deliver 3,4-bis(benzyloxy)phenol 8 in 87\% yield. Next, 8 was firstly protected with $\mathrm{PMBCl}$ and then selectively brominated with NBS to obtain polysubstituted bromobenzene $\mathbf{1}$ in high yield.

Subsequently, we aimed to synthesize 3-bromo-5-benzyloxy-7-acetoxyl-2-chromenone 3 (Scheme 2). According to reported methods [14], the commercially available phloroglucinol $\mathbf{1 0}$ and ethyl propiolate as starting materials smoothly underwent $\mathrm{ZnCl}_{2}$-catalyzed esterification and cyclization reactions to provide dihydroxycoumarin 11. Dihydroxycoumarin $\mathbf{1 1}$ was then treated with acetyl chloride to deliver the corresponding diacetoxylcoumarin 12 in good yield. The following reaction involved the dibromination and dehydrobromination of ketene 12 to afford 3-bromo-5,7-diacetoxyl-2-chromenone 13 in $75 \%$ yield. Reaction temperature is vital to the bromination reaction. It was found that maintaining the reaction temperature at $10{ }^{\circ} \mathrm{C}$ could avoid the bromination of acetyl group of $\mathbf{1 2}$ and acquire the optimal reaction yield. Finally, we ran the partial benzylation of 3-bromo-5,7-diacetoxyl-2-chromenone 13. The similar reactivity of the 5- and 7-hydroxy groups did not facilitate the selective 5-benzylation of 13. According to Humbert's selective alkylation reaction conditions [18], we tried similar normal benzylation conditions $\left(\mathrm{BnBr}, \mathrm{K}_{2} \mathrm{CO}_{3}\right.$, acetone, reflux) and found that traces of water in acetone chemoselectively hydrolyzed the 5-acetyl group as well, generating the intermediates $\mathbf{1 4}$ and $\mathbf{1 5}$, stabilized by the conjugating effect of the pyrone ring. Although the undesired deacetylation byproducts still existed, the major benzylating product was 3-bromo-5-benzyloxy-7-acetoxyl-2-chromenone 3 . With the use of ethanol recrystallization, the crude product 3 was obtained in $65 \%$ yield and directly used without further purification for the next step.

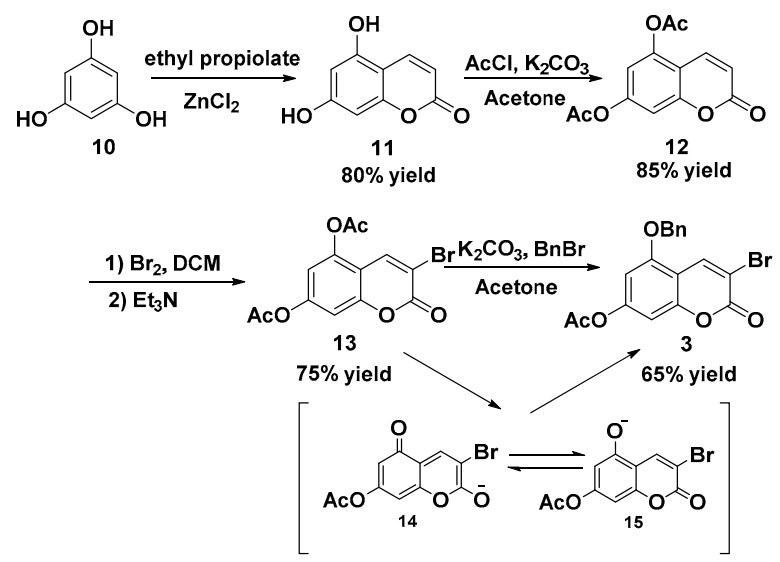

Scheme 2. Synthesis of 3-bromo-5-benzyloxy-7-acetoxyl-2-chromenone 3. 
With the key intermediates polysubstituted bromobenzene $\mathbf{1}$ and 3-bromo-5-benzyloxy-7-acetoxyl-2-chromenone 3 in hand, we focused on the combination of two fragments via boronation and a subsequent coupling reaction (Scheme 3). Under strong alkaline and low-temperature conditions [19], polysubstituted bromobenzene $\mathbf{1}$ could be treated with bis(pinacolato)diboron to afford the borate ester 2 . To simplify the operation procedure, Pd(II)-catalyzed boronation was attempted, and the corresponding borate ester 2 was obtained in quantitative yield as well. The formed crude product 2 could be utilized directly without further purification for the following Suzuki-Miyaura reaction and afforded the deacetyl coupling product 16 in good yield. To avoid the stability issue of borate ester in column chromatography, the boronation and subsequent coupling reaction were carried out conveniently in one pot and gave a $72 \%$ overall yield. The one-pot reaction conditions were optimized by initiating an experiment to evaluate the effect of the various parameters on the reaction yield (see Supplementary Materials). Methylation of the deacetyl coupling product 16 in the standard treatment with methyl iodide gave polysubstituted coumarin 4 in $85 \%$ yield.

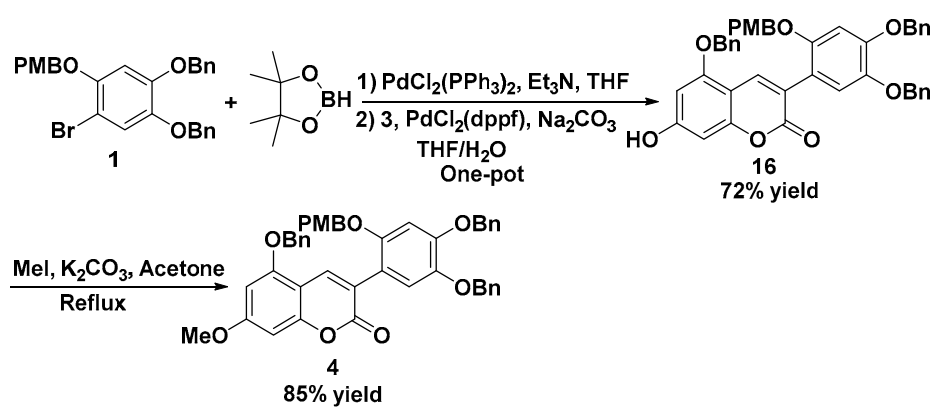

Scheme 3. Synthesis of polysubstituted coumarin 4 .

Finally, the completion of the remaining steps in WEL synthesis required PMB deprotection, cyclization, and debenzylation. Removing the PMB on the substituted coumarin 4 in acidic conditions (HOAc, reflux) led to the decomposed mixture and gave an unsatisfactory result [20]. It was reported that DDQ could also be used as a deprotecting reagent to remove the PMB group [21]. Thus, we adopted this synthetic strategy and hoped that oxidation cyclization could subsequently happen after the deprotection. Fortunately, DDQ-involved deprotection and oxidative annulation proceeded well as anticipated, forming the desired product 1,8,9-tris(benzyloxy)-3-methoxy-6H-benzofuro[3,2-c]chromen-6-one 17 in 56\% yield (Scheme 4). Compound 17 was then treated with $\mathrm{BCl}_{3}$ as a debenzylating reagent, generating the final product wedelolactone 5 in $81 \%$ yield. ${ }^{1} \mathrm{H}$ - and ${ }^{13} \mathrm{C}$-NMR spectra of the synthetic product were in agreement with reported data for WEL [13].

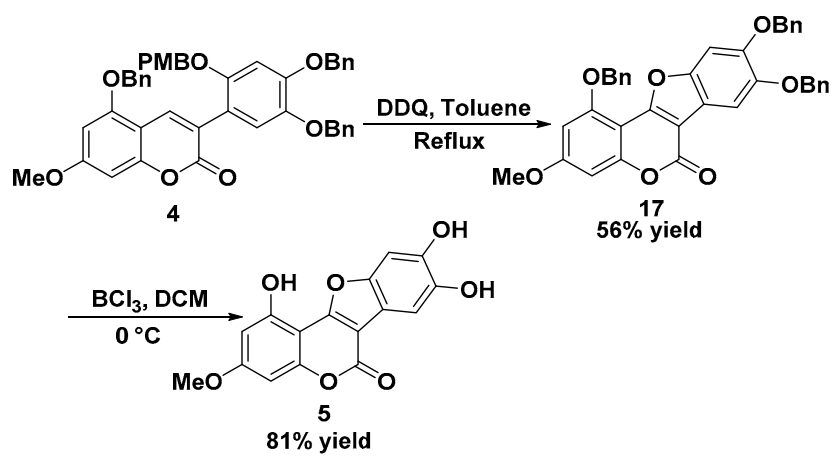

Scheme 4. Synthesis of wedelolactone 5. 


\subsection{Biological Activity}

With a sufficient amount of WEL in hand, we tested the in vitro tyrosinase activity. Kojic acid was used as a positive control, as typically employed in the evaluation of tyrosinase inhibitors. As shown in Figure 2, WEL caused strong tyrosinase inhibition in a concentration-dependent manner. The 50\% inhibitory concentration $\left(\mathrm{IC}_{50}\right)$ values of WEL and kojic acid were determined to be $1.2 \pm 0.3$ and 14.2 $\pm 1.6 \mu \mathrm{M}$, respectively. The strong tyrosinase inhibitory activity may be due to the multiple hydroxyl groups in the structure. However, this needs to be further confirmed by determining the derivatives of WEL (data not shown). To confirm the inhibitory mechanism of WEL against tyrosinase, the plots of initial velocity versus tyrosinase concentration at different concentrations of WEL were developed, and a set of straight lines was obtained (as shown in Figure 2). All of the lines passed through the origin, and an increase in the WEL concentration reduced the slopes of the lines, indicating that the compound was a reversible inhibitor.

(A)

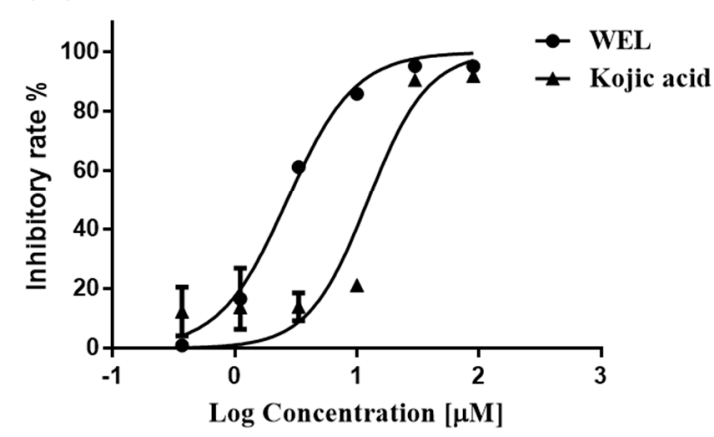

(B)

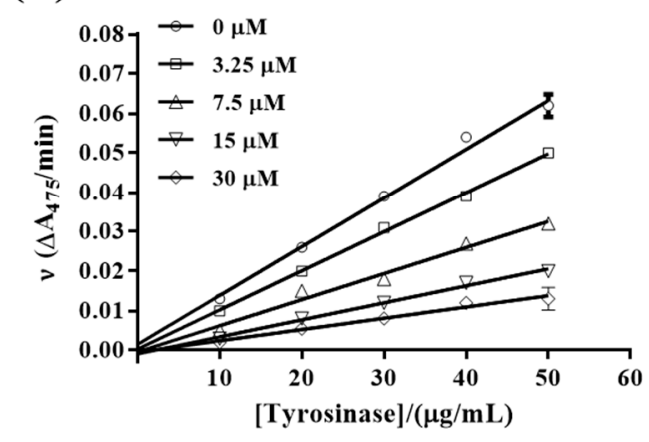

Figure 2. (A) Inhibitory activity of WEL and the control Kojic acid on tyrosinase. (B) Inhibitory mechanism of WEL on tyrosinase.

\subsection{The Docking Studies}

Computational docking studies were employed to determine the preferred binding sites of WEL in tyrosinase using the GOLD5.1 software. Tyrosinase contains two copper ions, and each copper ion is coordinated by three histidine residues. The first copper $(\mathrm{Cu} \mathrm{A})$ is coordinated by His61, His85, and His94, and the ligands of the second copper ion (Cu B) are His259, His163, and His 296 [21]. WEL could insert into the active site with a copper domain and it was found to interact with various amino-acid residues (Figure 3). The possible site of hydrogen-bonding interactions of WEL with tyrosinase was Asn260. The hydrogen-bonding residues could affect the binding affinity considerably. According to the molecular docking study, it was found that the His61, Val248, His259, Asn260, and His263 amino-acid residues of tyrosinase interact with WEL. The enzyme kinetic analysis and molecular docking studies confirmed that WEL binds to tyrosinase in the active site. 


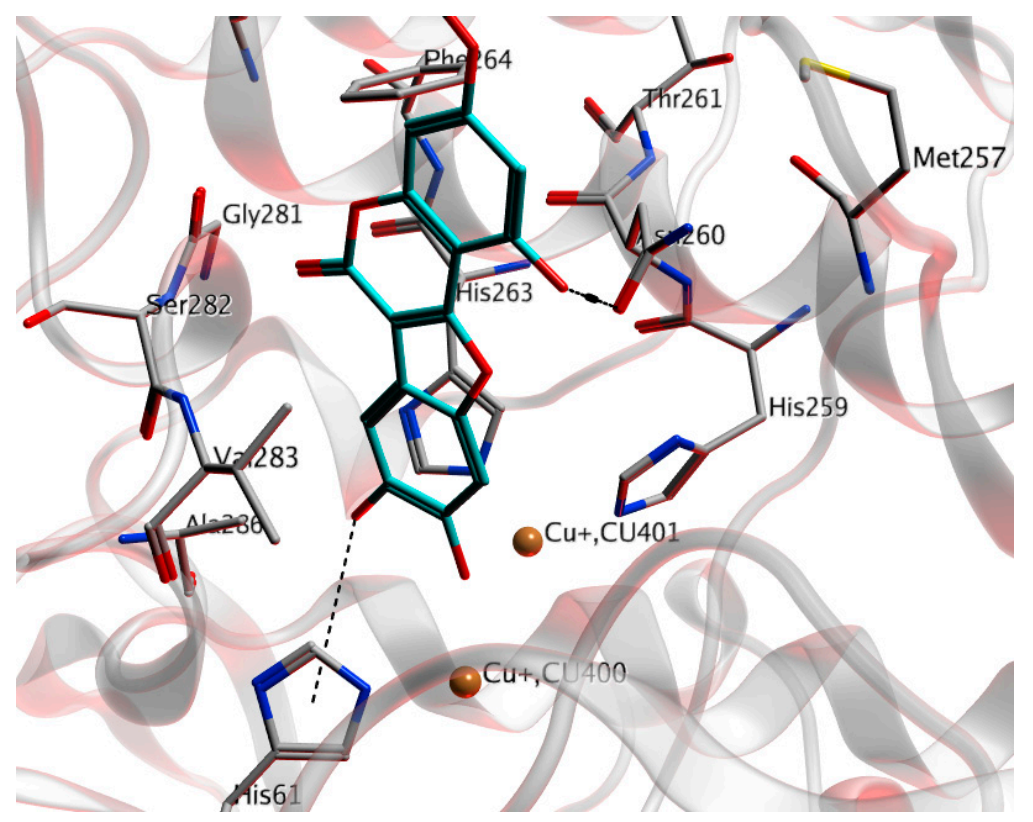

Figure 3. Computational docking simulations between tyrosinase and WEL obtained using GOLD5.1. The cyan stick structures indicate WEL and the white stick structures represent the amino-acid residues of tyrosinase. The copper ions are depicted as yellow balls. The black dotted lines represent hydrogen bonds.

\section{Materials and Methods}

\subsection{Reagents and Materials}

LC-2010 HPLC system (Shimadzu) equipped with a Phenomenex Luna C18 analytical column $(250 \mathrm{~mm} \times 4.6 \mathrm{~mm}, 5 \mu \mathrm{m})$, a 6520 Accurate-Mass Q-TOF LC/MS system (Agilent, Santa Clara, CA, USA) were obtained for this study. The chemical reagents, TYR and L-tyrosine were purachased from m Sigma-Aldrich (St. Louis, MO, USA). Koic acid was purchased from Shanghai Yuanye biological technology Co., Ltd. (purity $>98 \%$; Shanghai, China). Ultrapure water was prepared using a Millipore water purification system (Millipore, Bedford, MA, USA).

\subsection{Chemical Synthesis}

Preparation of 3,4-bis(benzyloxy)benzaldehyde 7: A 250-mL reaction vessel with a magnetic stirring bar was equipped with 3,4-dihydroxybenzaldehyde (5.13 g, $37.2 \mathrm{mmol}), \mathrm{K}_{2} \mathrm{CO}_{3}(25.70 \mathrm{~g}, 186.0 \mathrm{mmol}$ ), $\operatorname{BnBr}(19.0 \mathrm{~g}, 111.6 \mathrm{mmol})$, and DMF $(100 \mathrm{~mL})$. The mixture was stirred at room temperature for $4 \mathrm{~h}$. After the reaction was completed, water $(500 \mathrm{~mL})$ was added, and the mixture was extracted with ethyl acetate $(500 \mathrm{~mL})$. The organic layer was washed with water $(250 \mathrm{~mL} \times 2)$ and brine $(250 \mathrm{~mL})$. After drying over $\mathrm{MgSO}_{4}$, the extracts were filtered and concentrated. The residue was firstly stirred in hexane $(200 \mathrm{~mL})$ overnight and then filtered to afford the intermediate 7 without any purification for the next step. White solid; $10.17 \mathrm{~g}$, $86 \%$ yield; melting point (m.p.) $89-90^{\circ} \mathrm{C} ; \mathrm{R}_{\mathrm{f}}: 0.43$ (EA:hexane $=1: 4$ ); IR $\left(\mathrm{cm}^{-1}\right)$ : 3026, 2819, 2726, 1676, 1596, 1580, 1512, 1435, 1396, 1386, 1349, 1269, 1245, 1231, 1211, 1135, 1021; ${ }^{1} \mathrm{H}-\mathrm{NMR}\left(\mathrm{CDCl}_{3}, 300 \mathrm{MHz}\right): 5.24(\mathrm{~s}, 2 \mathrm{H}), 5.28(\mathrm{~s}, 2 \mathrm{H}), 7.05(\mathrm{~d}, J=8.1 \mathrm{~Hz}, 1 \mathrm{H}), 7.34-7.52$ $(\mathrm{m}, J=12.0 \mathrm{~Hz}, 12 \mathrm{~Hz}), 9.84(\mathrm{~s}, 1 \mathrm{H}) ;{ }^{13} \mathrm{C}-\mathrm{NMR}\left(\mathrm{CDCl}_{3}, 75 \mathrm{MHz}\right): 70.4,70.5,112.0,112.7,126.2,126.6$, 126.8, 127.5, 127.6, 128.1, 128.2, 129.9, 135.8, 136.1, 148.8, 153.9, 190.3 ppm; HR-MS (ESI) calculated for $\mathrm{C}_{21} \mathrm{H}_{19} \mathrm{O}_{3}[\mathrm{M}+\mathrm{H}] 319.1334$, found 319.1330 .

Preparation of 3,4-bis(benzyloxy)phenol 8: To a solution of compound 7 (8.60 g, $27.0 \mathrm{mmol})$ in DCM $(135 \mathrm{~mL})$ was added $m$-chloroperbenzoic acid $(7.00 \mathrm{~g}, 40.5 \mathrm{mmol})$, and then the mixture was stirred at room temperature for $15 \mathrm{~h}$. The reaction was quenched with saturated aqueous $\mathrm{Na}_{2} \mathrm{~S}_{2} \mathrm{O}_{3}$ solution $(25 \mathrm{~mL})$ and saturated aqueous $\mathrm{Na}_{2} \mathrm{CO}_{3}$ solution $(125 \mathrm{~mL})$. The mixture was firstly extracted with $\mathrm{DCM}$ 
$(125 \mathrm{~mL})$ and then successively washed with saturated aqueous $\mathrm{Na}_{2} \mathrm{CO}_{3}$ solution $(125 \mathrm{~mL} \times 2)$ and brine $(75 \mathrm{~mL})$. After drying over $\mathrm{Na}_{2} \mathrm{SO}_{4}$, the solvent was removed under vacuum. Next, the residue was firstly dissolved in $\mathrm{MeOH}(135 \mathrm{~mL})$ and then treated with $\mathrm{K}_{2} \mathrm{CO}_{3}(4.10 \mathrm{~g}, 29.7 \mathrm{mmol})$. The mixture was stirred at room temperature for $30 \mathrm{~min}$. After the reaction was completed, the solvent was removed under vacuum, and water $(100 \mathrm{~mL})$ was added. $\mathrm{HCl}$ solution $(3 \mathrm{M})$ was added to adjust the $\mathrm{pH}$ to 3 . The mixture was extracted with ethyl acetate $(250 \mathrm{~mL} \times 2)$. The combined organic layer was washed with brine $(200 \mathrm{~mL})$ and dried over $\mathrm{Na}_{2} \mathrm{SO}_{4}$. Finally, the extracts were filtered and concentrated to afford the intermediate 8 without any purification for the next step. White solid; $7.19 \mathrm{~g}, 87 \%$ yield; m.p. $105-106{ }^{\circ} \mathrm{C} ; \mathrm{R}_{\mathrm{f}}$ : 0.25 (EA:hexane = 1:4); IR $\left(\mathrm{cm}^{-1}\right): 3031,2926,1608,1508,1453,1435,1281,1269$, 1245, 1165, 1003; ${ }^{1} \mathrm{H}-\mathrm{NMR}\left(\mathrm{CDCl}_{3}, 300 \mathrm{MHz}\right): 5.09$ (s, 2H), 5.11 (s, 2H), 6.30-6.33 (m, 1H), 6.51 (s, $1 \mathrm{H}), 6.79-6.83(\mathrm{~m}, 1 \mathrm{H}), 7.28-7.44(\mathrm{~m}, 10 \mathrm{H}) ;{ }^{13} \mathrm{C}-\mathrm{NMR}\left(\mathrm{CDCl}_{3}, 75 \mathrm{MHz}\right): 70.6,72.4,102.9,106.5,117.2$, $126.8,127.2,127.3,127.4,127.9,128.0,136.5,137.1,142.3,149.8,150.4$ ppm; HR-MS (ESI) calculated for $\mathrm{C}_{20} \mathrm{H}_{19} \mathrm{O}_{3}[\mathrm{M}+\mathrm{H}]$ 307.1334, found 307.1336.

Preparation of 1,2-dibenzyloxy-4-(p-methoxybenzyl)oxybenzene 9: To a solution of compound 8 $(6.64 \mathrm{~g}, 21.7 \mathrm{mmol})$ in DMF $(20 \mathrm{~mL})$ was added $\mathrm{NaH}(60 \%$, dispersion in paraffin liquid) (1.05 g, $26.1 \mathrm{mmol})$ at $0{ }^{\circ} \mathrm{C}$. The mixture was stirred for $30 \mathrm{~min}$, and PMBCl (3.22 mL, $\left.23.9 \mathrm{mmol}\right)$ was added. The mixture was continually stirred at room temperature. After the reaction was finished according to TLC monitoring, the saturated $\mathrm{NH}_{4} \mathrm{Cl}$ solution $(100 \mathrm{~mL})$ was added, and the mixture was extracted with ethyl acetate $(100 \mathrm{~mL} \times 2)$. The organic layer was then washed with water $(100 \mathrm{~mL})$ and brine $(50 \mathrm{~mL})$ and dried over $\mathrm{Na}_{2} \mathrm{SO}_{4}$. The filtrate was concentrated, and the residue was stirred in hexane (75 mL) overnight. The mixture was filtered to provide the compound 9 without any purification for the next step. White solid; 8.32 g, 90\% yield; m.p. 80-81 ${ }^{\circ} \mathrm{C} ; \mathrm{R}_{\mathrm{f}}$ : 0.62 (EA:hexane = 1:4); IR (cm $\left.{ }^{-1}\right): 3062$, $3035,2914,2867,1610,1589,1515,1468,1418,1392,1380,1272,1228,1171,1116,1004 ;{ }^{1} \mathrm{H}-\mathrm{NMR}\left(\mathrm{CDCl}_{3}\right.$, $300 \mathrm{MHz}): 3.84(\mathrm{~s}, 3 \mathrm{H}), 4.92(\mathrm{~s}, 2 \mathrm{H}), 5.12(\mathrm{~s}, 2 \mathrm{H}), 5.15(\mathrm{~s}, 2 \mathrm{H}), 6.47-6.51(\mathrm{~m}, 1 \mathrm{H}), 6.68(\mathrm{~d}, J=8.7 \mathrm{~Hz}, 1 \mathrm{H})$, $6.88(\mathrm{~d}, J=8.7 \mathrm{~Hz}, 1 \mathrm{H}), 6.93(\mathrm{~s}, 1 \mathrm{H}), 6.95(\mathrm{~s}, 1 \mathrm{H}), 7.33-7.46(\mathrm{~m}, 12 \mathrm{H}) ;{ }^{13} \mathrm{C}-\mathrm{NMR}\left(\mathrm{CDCl}_{3}, 75 \mathrm{MHz}\right): 54.8$, 69.8, 70.6, 72.2, 103.4, 105.2, 113.5, 116.6, 126.9, 127.1, 127.2, 127.3, 127.9, 128.0, 128.6, 128.8, 136.6, 137.2, 142.7, 149.7, 153.7, 159.0 ppm; HR-MS (ESI) calculated for $\mathrm{C}_{28} \mathrm{H}_{27} \mathrm{O}_{4}[\mathrm{M}+\mathrm{H}]$ 427.1909, found 427.1909.

Preparation of 1,2-dibenzyloxy-4-bromo-5-(p-methoxybenzyl)oxybenzene $\mathbf{1}$ : To a solution of compound 8 (7.32 $\mathrm{g}, 17.2 \mathrm{mmol})$ in DMF $(185 \mathrm{~mL})$ was added the solution of NBS (3.21 $\mathrm{g}, 18.0 \mathrm{mmol})$ in DMF $(35 \mathrm{~mL})$ dropwise at $0{ }^{\circ} \mathrm{C}$. After stirring for $30 \mathrm{~min}$, the mixture was warmed to room temperature and stirred for additional $4 \mathrm{~h}$. When the reaction was completed, ice water (500 $\mathrm{mL})$ was added and a white solid appeared. After the suspension was filtered, the residue was washed with ice water, and dried under reduced pressure to give the intermediate 1 . White solid; $7.54 \mathrm{~g}, 87 \%$ yield; m.p. $103-104{ }^{\circ} \mathrm{C} ; \mathrm{R}_{\mathrm{f}}$ : 0.62 (EA:hexane = 1:4); IR $\left(\mathrm{cm}^{-1}\right)$ : 3058, 3012, 2910, 1589, 1520, 1420, 1395, 1375, 1225, 1180, 1123, 1001; ${ }^{1} \mathrm{H}-\mathrm{NMR}\left(\mathrm{CDCl}_{3}, 300 \mathrm{MHz}\right): 3.84(\mathrm{~s}, 3 \mathrm{H}), 4.96(\mathrm{~s}, 2 \mathrm{H}), 5.09(\mathrm{~s}, 2 \mathrm{H}), 5.10(\mathrm{~s}, 2 \mathrm{H}), 6.63(\mathrm{~s}, 1 \mathrm{H}), 6.92(\mathrm{~d}$, $J=8.7 \mathrm{~Hz}, 2 \mathrm{H}), 7.17(\mathrm{~s}, 1 \mathrm{H}), 7.33-7.46(\mathrm{~m}, 12 \mathrm{H}) ;{ }^{13} \mathrm{C}-\mathrm{NMR}\left(\mathrm{CDCl}_{3}, 75 \mathrm{MHz}\right): 54.8,71.4,71.5,72.1,103.0$, 104.4 113.5, 120.1, 126.9, 127.1, 127.4, 127.5, 128.0, 128.1, 128.2, 128.5, 136.3, 136.5, 143.7, 148.5, 149.5, 158.9 ppm; HR-MS (ESI) calculated for $\mathrm{C}_{28} \mathrm{H}_{25} \mathrm{BrKO}_{4}[\mathrm{M}+\mathrm{K}] 543.0573$, found 543.0559.

Preparation of 5,7-dihydroxy-2-chromenone 11: A stirred mixture of phloroglucinol dihydrate $(18.90 \mathrm{~g}, 150.0 \mathrm{mmol})$, ethyl propiolate $(17.7 \mathrm{~mL}, 180.0 \mathrm{mmol})$, and $\mathrm{ZnCl}_{2}(1.00 \mathrm{~g}, 7.5 \mathrm{mmol})$ was heated at $100{ }^{\circ} \mathrm{C}$ for $2 \mathrm{~h}$. A flocculent precipitate formed during the reaction. After the mixture was filtered, the solid was recrystallized from water to afford the intermediate 11. Yellow solid; 21.36 g, 80\% yield; m.p. 263-264 ${ }^{\circ} \mathrm{C}$; $\mathrm{R}_{\mathrm{f}}: 0.50$ (EA:hexane = 3:1); IR $\left(\mathrm{cm}^{-1}\right)$ : 3421, 3054, 1686, 1615, 1574, 1474, 1365, 1302, 1244, 1156, 1071; ${ }^{1} \mathrm{H}-\mathrm{NMR}\left(\mathrm{DMSO}-d_{6}, 300 \mathrm{MHz}\right): 5.94(\mathrm{~d}, J=9.6 \mathrm{~Hz}, 1 \mathrm{H}), 6.09(\mathrm{~m}, 1 \mathrm{H}), 6.17(\mathrm{~d}, J=2.1 \mathrm{~Hz}$, $1 \mathrm{H}), 7.86(\mathrm{dd}, J=5.7,9.6 \mathrm{~Hz}, 1 \mathrm{H}), 10.28(\mathrm{~s}, 1 \mathrm{H}), 10.56(\mathrm{~s}, 1 \mathrm{H}) ;{ }^{13} \mathrm{C}-\mathrm{NMR}$ (DMSO- $\left.d_{6}, 75 \mathrm{MHz}\right): 94.0$, 98.2, 101.6, 108.6, 139.5, 155.9, 156.4, 160.7, 162.0; HR-MS (ESI) calculated for $\mathrm{C}_{9} \mathrm{H}_{7} \mathrm{O}_{4}[\mathrm{M}+\mathrm{H}]$ 179.0344, found 179.0330 .

Preparation of 5,7-diacetoxyl-2-chromenone 12: A mixture of 11 (5.00 g, $28.0 \mathrm{mmol}$ ) and $\mathrm{K}_{2} \mathrm{CO}_{3}$ $(19.40 \mathrm{~g}, 140.0 \mathrm{mmol})$ in dry acetone was heated to reflux (oil bath, $90^{\circ} \mathrm{C}$ ) for $1 \mathrm{~h}$. Acetyl chloride $(8.0 \mathrm{~mL}, 112.3 \mathrm{mmol})$ was added dropwise with syringe. The reaction suspension was stirred for 
another $1.5 \mathrm{~h}$ at $90{ }^{\circ} \mathrm{C}$. The resulting solution was cooled down and filtrated out of the excess $\mathrm{K}_{2} \mathrm{CO}_{3}$. The solvent was concentrated in vacuo, and the residue was recrystallized by $\mathrm{MeOH}$ to give compound 12. White solid; $6.24 \mathrm{~g}, 85 \%$ yield; m.p. $129-130{ }^{\circ} \mathrm{C} ; \mathrm{R}_{\mathrm{f}}: 0.28$ (EA:hexane =1:2); IR $\left(\mathrm{cm}^{-1}\right): 3075,1767$, 1745, 1630, 1575, 1433, 1365, 1309, 1242, 1188, 1131, 1066, 1027; ${ }^{1} \mathrm{H}-\mathrm{NMR}$ (DMSO- $\left.d_{6}, 300 \mathrm{MHz}\right): 2.31$ (s, $3 \mathrm{H}), 2.40(\mathrm{~s}, 3 \mathrm{H}), 6.51(\mathrm{~d}, J=9.6 \mathrm{~Hz}, 1 \mathrm{H}), 7.11(\mathrm{~d}, J=2.1 \mathrm{~Hz}, 1 \mathrm{H}), 7.24(\mathrm{dd}, J=0.6,2.1 \mathrm{~Hz}, 1 \mathrm{H}), 8.07$ $(\mathrm{dd}, J=0.6,9.6 \mathrm{~Hz}, 1 \mathrm{H}) ;{ }^{13} \mathrm{C}-\mathrm{NMR}\left(\mathrm{DMSO}-d_{6}, 75 \mathrm{MHz}\right): 20.6,20.8,108.0,110.6,112.9,115.9,137.9$, 147.4, 152.6, 154.3, 159.2, 168.5, 168.8 ppm; HR-MS (ESI) calculated for $\mathrm{C}_{13} \mathrm{H}_{11} \mathrm{O}_{6}[\mathrm{M}+\mathrm{H}] 263.0556$, found 263.0538 .

Preparation of 3-bromo-5,7-diacetoxyl-2-chromenone 13: To a solution of $\mathbf{1 2}(2.00 \mathrm{~g}, 7.6 \mathrm{mmol})$ in $\operatorname{DCM}(20 \mathrm{~mL})$ was added $\mathrm{Br}_{2}(1.95 \mathrm{~mL}, 38.0 \mathrm{mmol})$ at $0{ }^{\circ} \mathrm{C}$. The mixture was stirred at $10{ }^{\circ} \mathrm{C}$ for $8 \mathrm{~h}$. The reaction was quenched with a $2 \mathrm{M} \mathrm{NaOH}$ aqueous solution $(25 \mathrm{~mL})$. The brown solution was extracted with DCM $(50 \mathrm{~mL})$. The organic layer was washed with water $(25 \mathrm{~mL} \times 2)$ and brine $(25 \mathrm{~mL})$ and then dried over $\mathrm{Na}_{2} \mathrm{SO}_{4}$. The filtrate was concentrated in vacuo to afford the dibromochromanone. To the above dibromide in DCM $(25 \mathrm{~mL})$ was added $\mathrm{Et}_{3} \mathrm{~N}(1.33 \mathrm{~g}, 13.2 \mathrm{mmol})$ at room temperature, which was then stirred for $1 \mathrm{~h}$. The resulting solution was removed from the solvent in vacuo, and the residue was recrystallized by $\mathrm{MeOH}$ to give the desired product 13 . White solid; $1.94 \mathrm{~g}$, 75\% yield; m.p. $130-131{ }^{\circ} \mathrm{C} ; \mathrm{R}_{\mathrm{f}}$ : 0.51(EA:hexane = 1:2); IR $\left(\mathrm{cm}^{-1}\right)$ : 3065, 1765, 1743, 1619, 1430, 1291, 1239, 1192, 1132, 1067, 1022; ${ }^{1} \mathrm{H}-\mathrm{NMR}\left(\mathrm{CDCl}_{3}, 300 \mathrm{MHz}\right): 2.34$ (s, 3H), 2.44 (s, 3H), 7.04-7.06 (m, $\left.2 \mathrm{H}\right), 8.11(\mathrm{~s}$, $1 \mathrm{H}) ;{ }^{13} \mathrm{C}-\mathrm{NMR}\left(\mathrm{CDCl}_{3}, 75 \mathrm{MHz}\right):$ 20.4, 20.6, 107.3, 110.4, 111.1, 112.2, 137.6, 145.9, 152.4, 153.4, 167.5, 167.6 ppm; HR-MS (ESI) calculated for $\mathrm{C}_{13} \mathrm{H}_{9} \mathrm{BrNaO}_{6}[\mathrm{M}+\mathrm{Na}] 362.9480$, found 362.9476 .

Preparation of 3-bromo-5-benzyloxy-7-acetoxyl-2-chromenone 3: To a solution of $\mathbf{1 3}$ (1.53 g, $4.5 \mathrm{mmol})$ and $\mathrm{K}_{2} \mathrm{CO}_{3}(1.88 \mathrm{~g}, 13.5 \mathrm{mmol})$ in acetone $(30 \mathrm{~mL})$ was added $\mathrm{BnBr}(0.81 \mathrm{~mL}, 6.8 \mathrm{mmol})$, and then the mixture was stirred at $56{ }^{\circ} \mathrm{C}$ overnight. The suspension was concentrated in vacuo, and water $(75 \mathrm{~mL})$ was added. The resulting solution was extracted with ethyl acetate $(100 \mathrm{~mL} \times 2)$. The combined organic layer was washed with brine $(100 \mathrm{~mL})$ and dried over $\mathrm{Na}_{2} \mathrm{SO}_{4}$. After the mixture was filtered, the filtrate was removed from the solvent and the residue was recrystallized by $\mathrm{EtOH}$ to give the desired product 3. White solid; $1.13 \mathrm{~g}, 65 \%$ yield; m.p. $176-177^{\circ} \mathrm{C} ; \mathrm{R}_{\mathrm{f}}$ : $0.60($ EA:hexane $=1: 2)$; IR $\left(\mathrm{cm}^{-1}\right)$ : $3091,2924,2853,1737,1615,1499,1459,1430,1351,1296,1234,1208,1131,1028 ;{ }^{1} \mathrm{H}-\mathrm{NMR}$ (DMSO- $d_{6}$, $300 \mathrm{MHz}): 2.31(\mathrm{~s}, 3 \mathrm{H}), 5.25(\mathrm{~s}, 2 \mathrm{H}), 6.93(\mathrm{~d}, J=1.3 \mathrm{~Hz}, 1 \mathrm{H}), 6.98(\mathrm{~d}, J=1.6 \mathrm{~Hz}, 1 \mathrm{H}), 7.36-7.45(\mathrm{~m}, 3 \mathrm{H})$, 7.51-7.54 (m, 2H), 8.39 (s, 1H); ${ }^{13}$ C-NMR (DMSO- $\left.d_{6}, 75 \mathrm{MHz}\right): 20.8,70.6,102.8,102.9,107.7,108.7,127.8$, 128.2, 128.5, 135.8, 138.9, 153.9, 154.0, 154.6, 156.3, 168.5 ppm; HR-MS (ESI) calculated for $\mathrm{C}_{18} \mathrm{H}_{14} \mathrm{BrO}_{5}$ $[\mathrm{M}+\mathrm{H}] 389.0025$, found 389.0022 .

Preparation of 5-(benzyloxy)-3-(4,5-bis(benzyloxy)-2-((4-methoxybenzyl)oxy)phenyl)-7-hydroxy2-chromenone 16: To a solution of $1(6.06 \mathrm{~g}, 12.0 \mathrm{mmol})$ and $\mathrm{Pd}\left(\mathrm{PPh}_{3}\right)_{2} \mathrm{Cl}_{2}(420 \mathrm{mg}, 0.6 \mathrm{mmol}, 5 \mathrm{~mol} \%)$ in THF (120 mL) was added TEA (14.4 mL, $103.0 \mathrm{mmol}, 8.6$ equivalents) and pinacoborane $(13.0 \mathrm{~mL}$, $90.0 \mathrm{mmol}, 7.5$ equivalents) under Ar atmosphere. The mixture was heated overnight at $80{ }^{\circ} \mathrm{C}$. After being cooled, 3 (3.18 g, $8.0 \mathrm{mmol}), \mathrm{Pd}(\mathrm{dppf}) \mathrm{Cl}_{2}(293 \mathrm{mg}, 0.4 \mathrm{mmol}, 5 \mathrm{~mol} . \%)$, and a solution of $\mathrm{Na}_{2} \mathrm{CO}_{3}(8.90 \mathrm{~g}, 84.0 \mathrm{mmol})$ in $\mathrm{H}_{2} \mathrm{O}(30 \mathrm{~mL})$ was added under Ar atmosphere. The mixture was stirred at $90{ }^{\circ} \mathrm{C}$ for another $12 \mathrm{~h}$, and a $3 \mathrm{M} \mathrm{HCl}$ solution was added to adjust the $\mathrm{pH}$ to 3 . The mixture was filtered with diatomaceous earth, and the filtrate was extracted with ethyl acetate $(200 \mathrm{~mL}$ $\times 3)$. The combined organic layer was washed with brine $(200 \mathrm{~mL})$ and then dried over $\mathrm{Na}_{2} \mathrm{SO}_{4}$. After drying and concentrating, the residue was purified by column chromatography with ethyl acetate/petroleum ether (1:3-1:1) to afford the desired product 16. Yellow solid; $3.98 \mathrm{~g}, 72 \%$ yield; m.p. 166-167 ${ }^{\circ} \mathrm{C} ; \mathrm{R}_{\mathrm{f}}: 0.32$ (EA:hexane = 1:2); IR $\left(\mathrm{cm}^{-1}\right)$ : 3425, 3012, 2988, 1725, 1613, 1520, 1443, 1400, 1387, 1312, 1214, 1189, 1102, 1043, 1004; ${ }^{1} \mathrm{H}-\mathrm{NMR}$ (DMSO-d $\left.d_{6}, 300 \mathrm{MHz}\right): 3.69$ (s, 3H), 4.95 (s, $\left.2 \mathrm{H}\right), 5.03$ (s, 2H), $5.19(\mathrm{~s}, 2 \mathrm{H}), 5.20(\mathrm{~s}, 2 \mathrm{H}), 6.37(\mathrm{~s}, 1 \mathrm{H}), 6.46(\mathrm{~s}, 1 \mathrm{H}), 6.77(\mathrm{~s}, 1 \mathrm{H}), 6.80(\mathrm{~s}, 1 \mathrm{H}), 6.98(\mathrm{~s}, 1 \mathrm{H}), 7.09(\mathrm{~s}$, 1H), 7.20-7.46 (m, 17H), $7.88(\mathrm{~s}, 1 \mathrm{H}) ;{ }^{13} \mathrm{C}-\mathrm{NMR}$ (DMSO-d, $\left.75 \mathrm{MHz}\right): 55.0,70.0,70.4,71.4,93.7,94.8$, 96.6, 98.0, 102.2, 102.5, 113.6, 116.9, 118.5, 127.5, 127.6, 127.7, 127.8, 128.0, 128.2, 128.4, 128.5, 128.9, 129.1, 136.3, 136.6, 137.1, 137.4, 141.8, 149.2, 150.8, 155.5, 155.9, 158.8, 159.8, 161.8 ppm; HR-MS (ESI) calculated for $\mathrm{C}_{44} \mathrm{H}_{37} \mathrm{O}_{8}[\mathrm{M}+\mathrm{H}]$ 693.2488, found 693.2484 . 
Preparation of 5-(benzyloxy)-3-(4,5-bis(benzyloxy)-2-((4-methoxybenzyl)oxy)phenyl)-7-methoxy-2chromenone 4: To a solution of 16 (1.38 g, $2.0 \mathrm{mmol})$ and $\mathrm{K}_{2} \mathrm{CO}_{3}(0.42 \mathrm{~g}, 3.0 \mathrm{mmol})$ in DMF $(10 \mathrm{~mL})$ was added MeI $(250 \mathrm{uL}, 4.0 \mathrm{mmol})$ slowly, and then the mixture was stirred at the room temperature. After TLC showed the reaction was completed, the mixture was diluted with ethyl acetate $(50 \mathrm{~mL})$, and the organic layer was washed with $\mathrm{H}_{2} \mathrm{O}(40 \mathrm{~mL} \times 2)$ and brine $(25 \mathrm{~mL})$. After drying over $\mathrm{Na}_{2} \mathrm{SO}_{4}$, the filtrate was concentrated, and the residue was purified by column chromatography with ethyl acetate/petroleum ether (1:3-1:2) to afford the desired product 4. Yellow solid; $1.20 \mathrm{~g}$, 85\% yield; m.p. 130-132 ${ }^{\circ} \mathrm{C}$; $\mathrm{R}_{\mathrm{f}}$ : 0.46 (EA:hexane = 1:2); IR $\left(\mathrm{cm}^{-1}\right)$ : 3031, 3005, 2927, 2835, 1719, 1610, 1513, 1445, 1413, 1385, 1300, 1250, 1197, 1155, 1109, 1082, 1015; ${ }^{1} \mathrm{H}-\mathrm{NMR}$ (DMSO-d $\left.6,300 \mathrm{MHz}\right): 3.69$ (s, 3H), 3.85 (s, 3H), $4.95(\mathrm{~s}, 2 \mathrm{H}), 5.04(\mathrm{~s}, 2 \mathrm{H}), 5.20(\mathrm{~s}, 2 \mathrm{H}), 5.25(\mathrm{~s}, 2 \mathrm{H}), 6.63(\mathrm{~d}, J=0.9 \mathrm{~Hz}, 2 \mathrm{H}), 6.76(\mathrm{~s}, 1 \mathrm{H}), 6.79(\mathrm{~s}, 1 \mathrm{H}), 7.00(\mathrm{~s}$, $1 \mathrm{H}), 7.11(\mathrm{~s}, 1 \mathrm{H}), 7.20(\mathrm{~s}, 1 \mathrm{H}), 7.23(\mathrm{~s}, 1 \mathrm{H}), 7.30-7.44(\mathrm{~m}, 11 \mathrm{H}), 7.46-7.49(\mathrm{~m}, 4 \mathrm{H}), 7.90(\mathrm{~s}, 1 \mathrm{H}) ;{ }^{13} \mathrm{C}-\mathrm{NMR}$ (DMSO- $d_{6}, 75 \mathrm{MHz}$ ): 55.0, 56.0, 70.2, 70.3, 70.4, 71.4, 93.0, 96.3, 102.2, 103.6, 113.6, 116.7, 118.4, 119.6, 127.6, 127.7, 127.8, 128.0, 128.2, 128.4, 128.5, 128.8, 129.1, 136.2, 136.4, 137.1, 137.4, 141.8, 149.4, 150.9, 155.5, 155.6, 158.8, 159.6, 163.0; HR-MS (ESI) calculated for $\mathrm{C}_{45} \mathrm{H}_{39} \mathrm{O}_{8}[\mathrm{M}+\mathrm{H}]$ 707.2645, found 707.2648.

Preparation of 1,8,9-tris(benzyloxy)-3-methoxy-6H-benzofuro[3,2-c]chromen-6-one 17: To a solution of $4(0.71 \mathrm{~g}, 1.0 \mathrm{mmol})$ in toluene $(20 \mathrm{~mL})$ was added DDQ $(0.45 \mathrm{~g}, 2.0 \mathrm{mmol})$, and then the mixture was stirred under reflux for $24 \mathrm{~h}$. After the reaction was finished, the mixture was concentrated and then purified by column chromatography (DCM) to give the product 17 . White solid; $327 \mathrm{mg}, 56 \%$ yield; m.p. $212-213^{\circ} \mathrm{C} ; \mathrm{R}_{\mathrm{f}}: 0.40$ (EA:hexane $\left.=1: 2\right) ; \mathrm{IR}\left(\mathrm{cm}^{-1}\right): 3031,2930,2850,1736,1604,1450,1401,1352$, 1301, 1273, 1197, 1161, 1137, 1081, 1049; ${ }^{1} \mathrm{H}-\mathrm{NMR}\left(\mathrm{CDCl}_{3}, 300 \mathrm{MHz}\right): 3.88$ (s, 3H), 5.25 (s, 2H), 5.27 (s, $2 \mathrm{H}), 5.31(\mathrm{~s}, 2 \mathrm{H}), 6.48(\mathrm{~d}, J=2.1 \mathrm{~Hz}, 1 \mathrm{H}), 6.63(\mathrm{~d}, J=2.1 \mathrm{~Hz}, 1 \mathrm{H}), 7.20(\mathrm{~s}, 1 \mathrm{H}), 7.37-7.63(\mathrm{~m}, 15 \mathrm{H}), 7.68(\mathrm{~s}$, 1H); ${ }^{13} \mathrm{C}-\mathrm{NMR}\left(\mathrm{CDCl}_{3}, 75 \mathrm{MHz}\right): 55.8,70.8,71.8,72.0,94.1,97.1,99.4,105.5,116.2,126.8,127.3,127.5$, 127.9, 128.0, 128.1, 128.5, 128.6, 128.7, 136.2, 136.8, 137.0, 148.0, 148.5, 150.1, 155.4, 155.9, 158.5, 159.7, 162.8; HR-MS (ESI) calculated for $\mathrm{C}_{37} \mathrm{H}_{28} \mathrm{NaO}_{7}[\mathrm{M}+\mathrm{Na}]$ 607.1733, found 607.1718.

Preparation of WEL 5: To a solution of $\mathbf{1 7}(0.58 \mathrm{~g}, 1.0 \mathrm{mmol})$ in DCM $(15 \mathrm{~mL})$ was added $\mathrm{BCl}_{3}$ $\left(3 \mathrm{~mL}, 1 \mathrm{M}\right.$ ) slowly at $0{ }^{\circ} \mathrm{C}$ under Ar atmosphere. After the reaction was finished, the mixture was concentrated and then purified by column chromatography $(\mathrm{MeOH}: \mathrm{DCM}=1: 20)$ to give the product 5 . Gray solid; $254 \mathrm{mg}, 81 \%$ yield; m.p. $>300{ }^{\circ} \mathrm{C}$; $\mathrm{R}_{\mathrm{f}}: 0.48$ (MeOH:DCM = 1:10); IR $\left(\mathrm{cm}^{-1}\right)$ : 3397, 2955, 2923, 2853, 1710, 1670, 1612, 1447, 1324, 1284, 1206, 1151, 1070, 1047; ${ }^{1} \mathrm{H}-\mathrm{NMR}$ (DMSO- $\left.d_{6}, 300 \mathrm{MHz}\right): 3.82$ (s, $3 \mathrm{H}), 6.45(\mathrm{~d}, J=1.8 \mathrm{~Hz}, 1 \mathrm{H}), 6.62(\mathrm{~d}, J=1.9 \mathrm{~Hz}, 1 \mathrm{H}), 7.16(\mathrm{~s}, 1 \mathrm{H}), 7.24(\mathrm{~s}, 1 \mathrm{H}) ;{ }^{13} \mathrm{C}-\mathrm{NMR}\left(\mathrm{DMSO}-d_{6}\right.$, $75 \mathrm{MHz}$ ): 55.7, 93.2, 96.7, 98.1, 98.8, 101.7, 104.5, 113.7, 144.3, 145.4, 148.8, 154.8, 155.2, 157.7, 158.9, 162.2; HR-MS (ESI) calculated for $\mathrm{C}_{16} \mathrm{H}_{11} \mathrm{O}_{7}[\mathrm{M}+\mathrm{H}]$ 315.0505, found 315.0504.

Characterization data of WEL reported by Yang's group were as follows: ${ }^{1} \mathrm{H}-\mathrm{NMR}$ (DMSO- $d_{6}$, $300 \mathrm{MHz}): 3.77(\mathrm{~s}, 3 \mathrm{H}), 6.40(\mathrm{~d}, J=2.1 \mathrm{~Hz}, 1 \mathrm{H}), 6.55(\mathrm{~d}, J=1.8 \mathrm{~Hz}, 1 \mathrm{H}), 7.15(\mathrm{~s}, 1 \mathrm{H}), 7.23(\mathrm{~s}, 1 \mathrm{H})$; ${ }^{13}$ C-NMR (DMSO- $d_{6}, 75$ MHz): 55.7, 93.2, 96.7, 98.1, 98.9, 101.7, 104.6, 113.8, 144.3, 145.4, 148.9, 154.8, $155.3,157.8,158.9,162.2$.

All above chemicals were commercially available and used without further purification. Analytical thin-layer chromatography was performed on glass plates precoated with silica gel impregnated with a fluorescent indicator $(254 \mathrm{~nm})$. The plates were visualized by exposure to ultraviolet light. ${ }^{1} \mathrm{H}-\mathrm{NMR}$ spectra were recorded on a Bruker DRX (300 MHz), and ${ }^{13} \mathrm{C}-\mathrm{NMR}$ spectra were recorded on a Bruker DRX (75 MHz). HR-MS spectra were taken on an Agilent Technologies Accurate-Mass Q-TQF LC/MS 6520.

\subsection{Biological Assays}

The tyrosinase inhibition activity of the compounds was measured using L-DOPA as a substrate according to a modified method of previous work $[4,10,11]$. WEL was firstly dissolved in DMSO at a concentration of $1.0 \mathrm{mM}$, and the final concentration of DMSO in the reaction mixture was $3 \%$. In the investigation, the total volume of the reaction system was $300 \mu \mathrm{L}$; L-DOPA was used as the substrate for the determination of diphenolase activity. Briefly, L-DOPA (100 $\mu \mathrm{L}, 0.5 \mathrm{mM})$, phosphate buffer $(180 \mu \mathrm{L}, \mathrm{pH} 6.8,50 \mathrm{mM})$, and different concentrations of inhibitors (10 $\mu \mathrm{L}$ in DMSO) 
were mixed and incubated at $30{ }^{\circ} \mathrm{C}$. Then, an aqueous solution of mushroom tyrosinase $(10 \mu \mathrm{L}$, $1000 \mathrm{U} / \mathrm{mL}$ ) was added to the above solution and mixed quickly. Absorption and kinetic measurements were carried out on a spectrophotometer from Thermo Fisher at $475 \mathrm{~nm}$. Control experiments, containing the same amount of DMSO without inhibitor, were routinely carried out. All measurements were performed in triplicate. The enzyme activity was calculated according to Lambert-Beer's law $\left(\varepsilon=3700 \mathrm{~L} \cdot \mathrm{mol}^{-1} \cdot \mathrm{cm}^{-1}\right)$. The extent of inhibition by the inhibitor was expressed as the concentration required to reduce tyrosinase activity to $50 \%\left(\mathrm{IC}_{50}\right)$. The percentage inhibition of tyrosinase activity was calculated as follows:

$$
\% \text { inhibition }=\left[1-\left(X-A_{1}\right) /\left(A_{2}-A_{1}\right)\right] \times 100 \% \text {, }
$$

where $\mathrm{X}$ is the absorbance at $475 \mathrm{~nm}$ of the inhibitor, $\mathrm{A}_{1}$ is the absorbance at $475 \mathrm{~nm}$ of the solution without tyrosinase, and $\mathrm{A}_{2}$ is the absorbance at $475 \mathrm{~nm}$ of the bank (without inhibitor).

\section{Conclusions}

In summary, we developed an efficient synthetic route to synthesize wedelolactone, wherein Pd(II)-catalyzed boronation/coupling reactions and DDQ-involved oxidative deprotection/annulation are key reactions. The obtained WEL was determined as an efficient tyrosinase inhibitor which could inhibit the enzyme in a reversible, competitive manner. Computational docking simulations showed that WEL could bind with tyrosinase because its hydroxyl group on the scaffold bound residue Asn260 located in the active site. The study suggested that WEL may be efficient in restricting enzymatic browning reactions, which could be widely used in multiple fields.

Supplementary Materials: The following are available online. Table S1: Optimization of boronation/Suzuki-Miyaura reactions; ${ }^{1} \mathrm{H}$ NMR and ${ }^{13} \mathrm{C}$ NMR spectra of the products.

Author Contributions: F.J. designed the experiments and wrote the manuscript; H.H. performed the in silico molecular docking simulation and in vitro experiments, synthesized the compounds, and wrote the manuscript; J.C. revised the manuscript; C.Z. advised on data interpretation; J.R. synthesized the compounds.

Funding: This work was supported by grants from the National Natural Science Foundation of China (No. 81903498).

Conflicts of Interest: The authors declare no conflicts of interest.

\section{References}

1. Zolghadri, S.; Bahrami, A.; Hassan Khan, M.T.; Munoz-Munoz, J.; Garcia-Molina, F.; Garcia-Canovas, F.; Saboury, A.A. A comprehensive review on tyrosinase inhibitors. J. Enzyme Inhib. Med. Chem. 2019, 34, 279-309. [CrossRef] [PubMed]

2. Wang, H.M.; Chen, C.Y.; Chen, C.Y.; Ho, M.L.; Chou, Y.T.; Chang, H.C.; Lee, C.H.; Wang, C.Z.; Chum, I.M. (-)-N-Formylanonaine from Michelia alba as a human tyrosinase inhibitor and antioxidant. Bioorg. Med. Chem. 2010, 18, 5241-5247. [CrossRef] [PubMed]

3. Akhtar, M.N.; Sakeh, N.M.; Zareen, S.; Gul, S.; LoKM Ul-Haq, Z.; Shah, S.A.A.; Ahmad, S. Design and synthesis of chalcone derivatives as potent tyrosinase inhibitors and their structural activity relationship. J. Mol. Struct. 2015, 1085, 97-103. [CrossRef]

4. Ullah, S.; Kang, D.; Lee, S.; Ikram, M.; Park, C.; Park, Y.; Yoon, S.; Chun, P.; Moon, H.R. Synthesis of cinnamic amide derivatives and their anti-melanogenic effect in $\alpha-\mathrm{MSH}$-stimulated B16F10 melanoma cells. Eur. J. Med. Chem. 2019, 161, 78-92. [CrossRef]

5. Asanuma, M.; Miyazaki, I.; Ogawa, N. Dopamine-or L-DOPA-induced neurotoxicity: The role of dopamine quinone formation and tyrosinase in a model of Parkinson's disease. Neurotox. Res. 2003, 5, 165-176. [CrossRef]

6. Ashraf, Z.; Rafiq, M.; Seo, S.Y.; Kwon, K.; Babar, M.M.; Zaidi, N.U. Kinetic and in silico studies of novel hydroxy-based thymol analogues as inhibitors of mushroom tyrosinase. Eur. J. Med. Chem. 2015, 98, $203-211$. [CrossRef] 
7. Pillaiyar, T.; Namasivayam, V.; Manickam, M.; Jung, S.H. Inhibitors of melanogenesis:an updated review. J. Med. Chem. 2018, 17, 7395-7418. [CrossRef]

8. Ogiwara, Y.; Sugiura, M.; Watanabe, K.; Tawara, J.; Endo, E.; Maruyama, H.; Tsuji, S.; Matsue, K.; Yamada, H.; Wako, Y. Evaluation of the repeated-dose liver, bone marrow and peripheral blood micronucleus and comet assays using kojic acid. Mutat. Res. Genet. Toxicol. Environ. Mutagen. 2015, 780, 111-116. [CrossRef]

9. Wagle, A.; Seong, S.H.; Jung, H.A.; Choi, J.S. Identifying an isoflavone from the root of Pueraria lobata as a potent tyrosinase inhibitor. Food Chem. 2019, 276, 383-389. [CrossRef]

10. Muñoz, E.; Avila, J.G.; Alarcón, J.; Kubo, I.; Werner, E.; Céspedes, C.L. Tyrosinase inhibitors from Calceolaria integrifolia s.1.: Calceolaria talcana aerial parts. J. Agric. Food Chem. 2013, 61, 4336-4343. [CrossRef]

11. Dong, X.; Zhang, Y.; He, J.L.; Zhang, S.; Zeng, M.M.; Chen, J.; Zheng, Z.P. Preparation of tyrosinase inhibitors and antibrowning agents using green technology. Food Chem. 2016, 197, 589-596. [CrossRef] [PubMed]

12. Govindachari, T.R.; Nagarajan, K.B.; Pai, B.R. Chemical examination of Wedelia calendulacea. Part I. Structure of wedelolactone. J. Chem. Soc. (Resumed) 1956, 629-632. [CrossRef]

13. Chang, C.; Yang, L.; Chang, S.; Fang, Y.; Lee, Y. Total synthesis of demethylwedelolactone and wedelolactone by Cu-mediated/Pd(0)-catalysis and oxidative-cyclization. Tetrahedron 2008, 64, 3661-3666. [CrossRef]

14. Li, C.C.; Xie, Z.X.; Zhang, Y.D.; Chen, J.H.; Yang, Z. Total synthesis of wedelolactone. J. Org. Chem. 2003, 68, 8500-8504. [CrossRef]

15. Kraus, G.A.; Zhang, N. Hydrogen-atom Abstraction/Cyclization in synthesis. Direct syntheses of coumestan and coumestrol. J. Org. Chem. 2000, 65, 5644-5646.

16. Zheng, S.; Shen, Z. Total synthesis of hirtellaniine A. Tetrahedron Lett. 2010, 51, 2883-2887. [CrossRef]

17. Neagoie, C.; Vedrenne, E.; Buron, F.; Merour, J.; Rosca, S.; Bourg, S.; Lozach, O.; Meijer, L.; Baldeyrou, B.; Lansiaux, A.; et al. Synthesis of chromeno[3,4- $b$ ]indoles as Lamellarin D analogues: A novel DYRK1A inhibitor class. Eur. J. Med. Chem. 2012, 49, 379-396. [CrossRef]

18. Roux, D.; Makki, S.; Bevalot, F.; Humbert, P. Efficient total synthesis of 5-methoxypsoralen. Synlett 2007, 1, 129-130. [CrossRef]

19. Donohoe, T.J.; Jones, C.R.; Barbosa, L.C.A. Total synthesis of ( \pm )-Streptonigrin: De novo construction of a pentasubstituted pyridine using ring-Closing metathesis. J. Am. Chem. Soc. 2011, 133, 16418-16421. [CrossRef]

20. Hodgetts, K.J.; Wallace, T.W. Cleavage or acetyl-de-alkylation of 4-methoxybenzyl (MPM) ethers using acetic acid. Synth. Commun. 1994, 24, 1151-1155. [CrossRef]

21. Green, R.A.; Jolley, K.E.; Al-Hadedi, A.A.M.; Pletcher, D.; Harrowven, D.C.; Frutos, O.D.; Mateos, C.; Klauber, D.J.; Rincon, J.A.; Brown, R.C.D. Electrochemical deprotection of para-methoxybenzyl ethers in a flow electrolysis cell. Org. Lett. 2017, 19, 2050-2053. [CrossRef] [PubMed]

Sample Availability: Samples of the compounds 4, 5 and 16 are available from the authors.

(C) 2019 by the authors. Licensee MDPI, Basel, Switzerland. This article is an open access article distributed under the terms and conditions of the Creative Commons Attribution (CC BY) license (http://creativecommons.org/licenses/by/4.0/). 